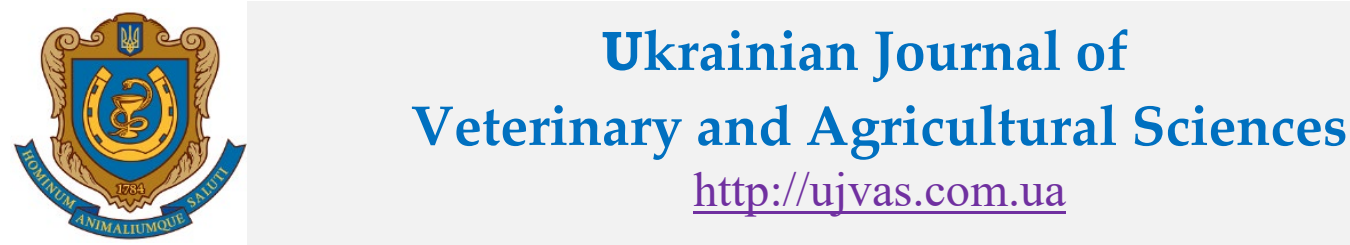

Stepan Gzhytskyi National University of Veterinary Medicine and Biotechnologies Lviv

original article $\mid$ UDC 619:615.015.4:636.5 $\mid$ doi: 10.32718/ujvas2-3.05

Volume 2

Number 3

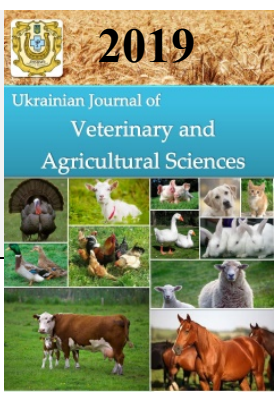

\title{
The intensity of the processes of oxidative modification of proteins and the activity of enzymes of the antioxidant protection system of broiler chickens under the action of vitamins $E$ and $C$
}

\author{
L. Romanovych ${ }^{1}$, B. Kurtyak ${ }^{1}$, D. Mudrak ${ }^{2}$ \\ ${ }^{1}$ Stepan Gzhytskyi National University of Veterinary Medicine and Biotechnologies, Pekarska, Str., 50, Lviv, 79010, Ukraine \\ ${ }^{2}$ Institute of Animal Biology NAAS, Vasyl Stus Str., 38, Lviv, 79034, Ukraine
}

\begin{tabular}{l} 
Article info \\
Received 04.11.2019 \\
Received in revised form \\
04.12 .2019 \\
Accepted 05.12.2019 \\
\hline Correspondence author \\
Ludmila Romanovych \\
Tel.: +38-067-859-05-07 \\
E-mail: romanovychlv@gmail.com \\
\hline 2019 Romanovych L. et al. This is \\
an open-access article distributed \\
under the terms of the Creative \\
Commons Attribution License, \\
which permits unrestricted use, \\
distribution, and reproduction in any \\
medium, provided the original \\
author and source are credited. \\
$\begin{array}{l}\text { (cc)) Br } \\
\end{array}$
\end{tabular}

Contents

1. Introduction

2. Materials and methods...... 19

4. Conclusions ............... 22

References .................... 22

\begin{abstract}
Chickens in the control group received a standard ration, the first experimental - ration with the addition of tocopherol acetate, the second experimental - ascorbic acid, and the third - a complex of these vitamins. On the basis of the conducted researches the influence of vitamin supplements on the indexes of oxidation intensity of lipid and protein structures was analyzed. The intensity of the processes of oxidative modification of proteins largely depends on the level of vitamins E and C in the ration of broiler chickens. Supplementation with vitamin C and with vitamin $\mathrm{E}$ resulted in an inhibitory influence on the content of OMP products, the level of which is largely regulated by the enzyme and non-enzymatic links of the antioxidant protection system. Searches have shown the stimulating influence of the addition of vitamins on the activity of antioxidant enzymes. In particular, SOD activity increased by $19 \%$ on the 34 th day, by $32 \%$ on the 41 st day, whereas glutathione peroxidase activity was 5.7 and $20.8 \%$, respectively, compared to the control chickens group. An increase in the activity of antioxidant enzymes occurred against the background of a decrease in the intensity of oxidation processes. At the same time, there was also an increase in the content of recovered glutathione in the blood of chickens of the second and third experimental groups at $34^{\text {th }}$ and $41^{\text {st }}$ days of age. Thereby, searches have shown that supplementing the ration with vitamins $\mathrm{E}$ and $\mathrm{C}$ with a positive influence on the organism's adaptive capacity and antioxidant potential, which is extremely important to ensure the metabolic homeostasis of chickens during critical periods of their cultivation.
\end{abstract}

Key words: biochemistry, antioxidant protection system, oxidative modification of proteins, broiler chickens, vitamins $\mathrm{E}$ and $\mathrm{C}$.

\section{Citation:}

Romanovych, L., Kurtyak, B., \& Mudrak, D. (2019). The intensity of the processes of oxidative modification of proteins and the activity of enzymes of the antioxidant protection system of broiler chickens under the action of vitamins E and C. Ukrainian Journal of Veterinary and Agricultural Sciences, 2(3), 19-22.

\section{Introduction}

Modern industrial poultry farming practices involve intensive technologies, which do not always correspond to the physiological characteristics of the poultry organism. One of the biggest problems in this field is the decline in the viability of poultry, especially in broiler chickens. The presence of age dynamics and critical periods in the development of immunobiological reactivity in the postnatal development period and the action of anthropogenic factors cause stress that destabilizes the metabolic processes in the body of a poultry. The search of molecular mechanisms of action of stress factors indicate a free radical theory of stress occurrence. Free radicals damage all types of biological molecules, lipids, proteins, and nucleic acids (Hopps et al., 2010; Ward, 2010; Ziech et al., 2010). In response to stress, antibodies, stressors, and adapter proteins are synthesized to maintain cellular homeostasis, which enhance the destruction and autolysis of cells in the organism (Calderwood et al., 2009; Park \& Yun, 2009; Lu et al., 2010). In the protective mechanisms of development of free radical reactions the antioxidant protection system is the leading one (AFO) (Harwell, 2007; Malakhov \& Monastyrskyi, 2010; Iskra \& Janovich, 2012).

In recent years, the considerable interest of scientists has increased to investigate the mechanisms of interaction of active oxygen forms (AOF) with proteins. The actuality of such investigations is due to the extremely important importance of proteins in the body's metabolic processes. It is well known, that all enzymes, which provide an endless multifaceted metabolic link and regulatory processes are proteins (Armstrong, 2002; Jeschke et al., 2008).

It has now become apparent that one of the main causes of chicken death and low viability of chickens is the imbal- 
ance of protein-vitamin-mineral feeding (Kots, 2005). However, it should be noted that the most complete vitamin support of the poultry ration, especially vitamins $\mathrm{E}$ and $\mathrm{C}$ at critical periods, it is important to obtain healthy viable chickens (Karadas et al., 2005).

The progress made in recent years in improving poultry production and in increasing the production of poultry meat and eggs is closely linked to the successes in the study of metabolic features in poultry. The results obtained are the theoretical foundation for the nutrition and modern standards of poultry feeding and use in their rations of feed additives, mineral and vitamin premixes.

In their searches, many authors have stated the stimulating influence of vitamins $\mathrm{E}$ and $\mathrm{C}$ on the activity of the immune and antioxidant system, productivity and safety in chickens (Mudrak \& Ohorodnyk, 2007; Mudrak \& Vishchur, 2011). However, in broiler chickens the searches of such a plan are fragmentary. To date, both the independent and the combined influence of vitamins $\mathrm{C}$ and $\mathrm{E}$ on the activity of the protective systems of the poultry organism have not been sufficiently studied. First and foremost, finding out requires the investigation of the influence of vitamins $\mathrm{E}$ and $\mathrm{C}$ on the state of the antioxidant protection system in broiler chickens during critical growth periods.

\section{Materials and methods}

The searches were carried out at the "Fedjuk M" farm in the village of Novosilky, Zolochiv district, Lviv region on four groups of broiler chickens of 100 heads in each, from 1 to 41 days of age. Keeping chickens was outdoor with free access to feed and water. The control group of chickens was fed a standard compound feed balanced on the basic nutrients according to the norms recommended for the ROSS308 cross. The first experimental group of chickens in addition to the specified feed received - tocopherol acetate in the amount of $0.1 \mathrm{~g} / \mathrm{kg}$ of compound feed, the second is ascorbic acid of $0.25 \mathrm{~g} / \mathrm{kg}$ of compound feed. The third experimental group of chickens - tocopherol acetate and ascorbic acid at these doses.

For biochemical searches, blood was taken from the chickens after decapitation in different ages: 11-, 27-, 34-, and 41-daily age (five individuals from each group).

In hemolysates of erythrocytes blood of chickens was determined: glutathione peroxidase activity (EC 1.11.1.9) according to V. M. Moin (1986), superoxide dismutase (EC 1.15.1.1) - according to the method described by E. E. Du- binina et al. (1983), the content of reduced glutathione by the method described by E. Butler (1963).

In the blood plasma was determined: the content of aldehyde and ketone derivatives of oxidative modification of proteins (OMP370 and OMP430), as described in R. L. Levine et al. (1990).

During the work, the bioethical requirements of the animals were complied with according to the current legislation.

The resulting digital data were statistically processed using Microsoft Excel for PCs, using conventional methods of variational statistics with determination of mean values $(\mathrm{M})$, their quadratic error $(\mathrm{m})$, and significance of differences established by Student's t-test.

\section{Results and discussion}

It is known that under conditions of oxidative stress and excessive generation of AEO, processes of uncontrolled protein modification is developing, that cause protein fragmentation, their denaturation, and also the formation of primary amino acid radicals, further engaging in secondary interaction with adjacent amino acid residues, and in general, it creates a rather complicated picture of the damaging action of AEO on protein macromolecules. All this leads to the loss of their biological activity by proteins and disruption of metabolic processes, in particular regenerative processes (Armstrong, 2002; Martyshuk et al., 2016; Lavryshyn et al., 2016; Gutyj et al., 2018; Lavryshyn \& Gutyj, 2019).

As shown by the results of the investigations (table 1) in chickens of the control group with age the intensity of the processes of oxidative modification of proteins (OMP) remained virtually unchanged and was approximately at the same level as indicated by blood plasma aldehyde and ketone derivatives of OMP. Additional introduction to the ration of vitamins $\mathrm{E}$ and $\mathrm{C}$ had an influence on the intensity of the processes of oxidative modification of proteins. In particular, the content of aldehyde and ketone derivatives of OMP in the serum of chickens in all investigation periods, to which vitamin $\mathrm{C}$ was added to the ration was lower than in the control. In this case, differences in control were found to be significant in the content of $\mathrm{OMP}_{370}$ in the blood of 27 and 34-daily age chickens, and $\mathrm{OMP}_{430}$ at 34- and 41-daily age. Similar changes were observed in chickens, to which vitamins $\mathrm{C}$ and $\mathrm{E}$. were added to the compound feed. Thus, at 34- and 41-daily age the content of aldehyde and ketone derivatives of OMP in the blood of chickens in this group was lower $(\mathrm{P}<0.01-0.001)$ than in the control one.

Table 1

The content of aldehyde $\left(\mathrm{OMP}_{370}\right)$ and ketone $\left(\mathrm{OMP}_{430}\right)$ derivatives of oxidative protein modification in the blood of broiler chickens $(\mathrm{M} \pm \mathrm{m} ; \mathrm{n}=5)$

\begin{tabular}{|c|c|c|c|c|}
\hline \multirow{2}{*}{ Indicators } & \multirow{2}{*}{ Groups } & \multicolumn{3}{|c|}{ Age of broiler chickens, days } \\
\hline & & 27 & 34 & 41 \\
\hline \multirow{4}{*}{$\begin{array}{c}\mathrm{OMP}_{370} \mathrm{nmol} / \mathrm{mg} \text { of pro- } \\
\text { tein }\end{array}$} & $\mathrm{K}$ & $4.02 \pm 0.01$ & $4.16 \pm 0.02$ & $4.0 \pm 0.27$ \\
\hline & E1 & $4.09 \pm 0.03$ & $3.73 \pm 0.12^{* *}$ & $3.9 \pm 0.43$ \\
\hline & E2 & $3.57 \pm 0.02^{* *}$ & $3.46 \pm 0.19^{* *}$ & $3.2 \pm 0.27$ \\
\hline & E3 & $4.05 \pm 0.07$ & $3.74 \pm 0.11^{* *}$ & $3.3 \pm 0.23^{* * *}$ \\
\hline \multirow{4}{*}{$\begin{array}{c}\mathrm{OMP}_{430} \mathrm{nmol} / \mathrm{mg} \text { of pro- } \\
\text { tein }\end{array}$} & $\mathrm{K}$ & $10.26 \pm 0.08$ & $9.71 \pm 0.12$ & $10.13 \pm 0.07$ \\
\hline & E1 & $10.14 \pm 0.12$ & $9.40 \pm 0.23$ & $9.24 \pm 0.60$ \\
\hline & $\mathrm{E} 2$ & $10.02 \pm 0.15$ & $7.77 \pm 0.48^{* *}$ & $8.59 \pm 0.12^{* * *}$ \\
\hline & E3 & $10.22 \pm 0.18$ & $8.05 \pm 0,53^{*}$ & $8.30 \pm 0.19^{* * *}$ \\
\hline
\end{tabular}

Note. Differences are statistically significant compared to controls: $*-\mathrm{P}<0.05 ; * *-\mathrm{P}<0.01 ; * * *-\mathrm{P}<0.001$ 
At the same time, as shown in Table 1, additional introduction of vitamin $\mathrm{E}$ to the ration of broiler chickens caused a likely increase in the content of $\mathrm{OMP}_{430}$ in the blood of chickens 27 and 34 days of age and a decrease in the level of $\mathrm{OMP}_{370}$ by 34 days of life, indicating its verified impact on the content of derived OMPs.

Thus, the results of the investigations show that the intensity of the processes of oxidative modification of proteins largely depends on the level of vitamins $\mathrm{E}$ and $\mathrm{C}$ in the ration of broiler chickens. Supplementation with vitamin $\mathrm{C}$ and also with vitamin $\mathrm{E}$ to the ration caused an inhibitory influence on the content of OMP products, the level of which is largely regulated by the enzymatic and nonenzymatic links of the antioxidant defense system. The lower content of OMP products in the blood of chickens of the second and third experimental groups relative to the control may indicate higher functional activity of the antioxidant protection system.

From the data shown in Figure 1 we can see that glutathione peroxidase activity in the blood of chickens of the third experimental group on the 34th and 41st days was respectively $5.7(\mathrm{P}<0.05)$ and $20.8 \%(\mathrm{P}<0.05)$ higher than in the control one. In this case in the 27 and 34 days of age, there was a tendency to increase glutathione peroxidase activity in the blood of chickens, which additionally to the standard compound feed received vitamin $\mathrm{C}$, and at 41 days of age, differences in the control group were likely. From the literature it is known that glutathione peroxidase is localized in the cell cytosol and is one of the main components of the organism's defense system from endogenous or exogenously induced peroxide formation (including lipid peroxides). Its active center includes selenium in the form of selenocysteine, which provides the antioxidant function of this enzyme (Flohe, 1989; Pehrson et al., 1989). Due to the catalytic activity of GP in cells, the reduction of hydrogen peroxide and hydroperoxides of organic molecules to the corresponding hydroxyl compounds occurs. This process is accomplished by the use of reduced glutathione hydrogen, to which the enzyme exhibits high affinity (Vannuechi, 1991).
GPx, nM GSH/min x mg protein

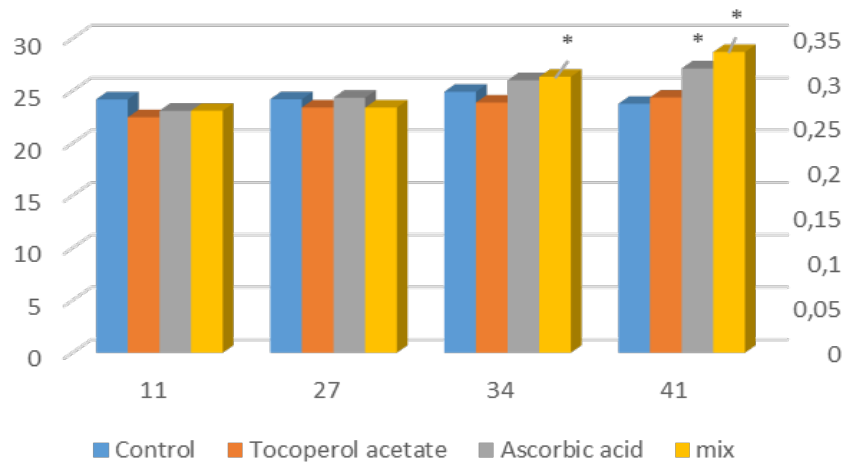

$\mathrm{GSH} \mu \mathrm{M} / \mathrm{ml}$

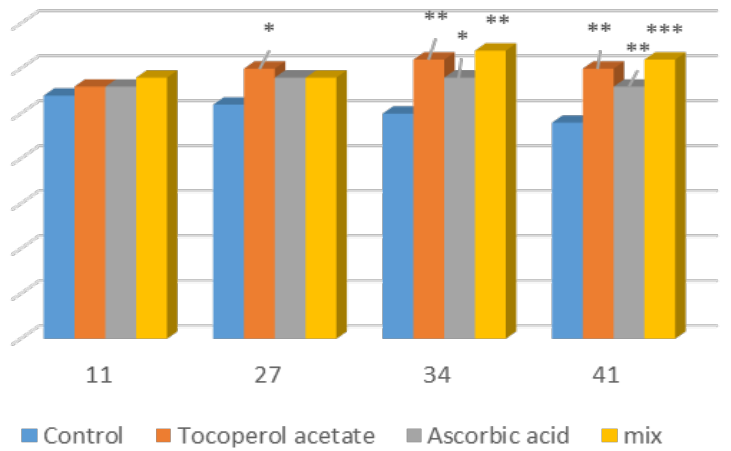

Fig. 1. Glutathione peroxidase activity and content of reduced glutathione in broiler chickens blood $(M \pm m ; n=5)$

From the data in Figure 1 we can see that the content of reduced glutathione in the blood of chickens in the first experimental group at 27-, 34- and 41-daily age was higher $(\mathrm{P}<0.05-0.01)$ than in the control one. At the same time, there was also an increase $(\mathrm{P}<0.05-0.01)$ in the content of recovered glutathione in the blood of chickens of the second and third experimental groups at 34 and 41 days of age. In the system of antioxidant protection of the organism was proved that the restored glutathione is the most powerful source of electrons for the restoration of oxidized compounds. Investigation of its content in the blood of animals is a diagnostically justifiable indicator of the sustainability of metabolic processes and of the antioxidant potential as a whole. Similar changes, only less pronounced, were found in the investigation of superoxide dismutase activity - the primary link of the antioxidant defense system. It was specifically identified higher $(\mathrm{P}<0.05)$ superoxide dismutase activity in the blood of the third group of chickens at 34 and 41 days of age. (Fig. 2).

Therefore, the results of the investigations showed that additional introduction to the ration of poultry vitamins $\mathrm{E}$ and $\mathrm{C}$ has a positive influence on the adaptive capacity and antioxidant potential of the organism, which is extremely important to ensure the metabolic homeostasis of chickens during critical periods of their growth.

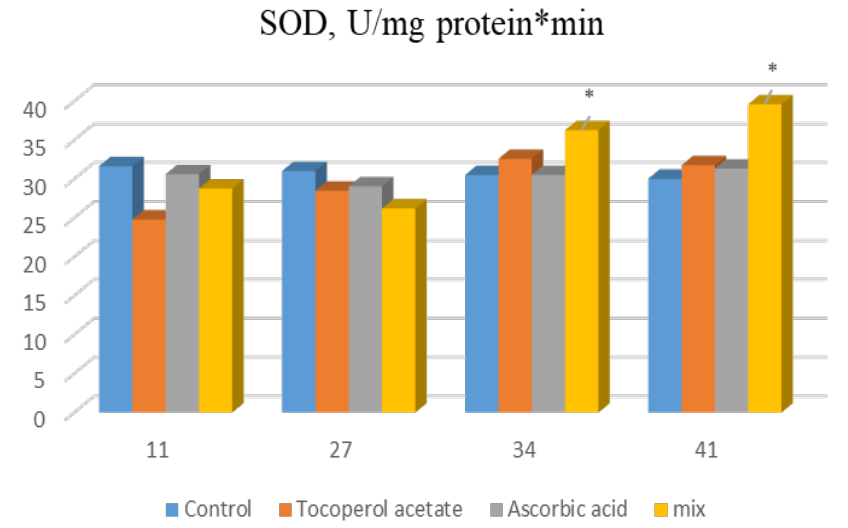

Fig. 2. Superoxide dismutase activity of blood erythrocytes of broiler chickens $(M \pm m ; n=5)$

Both alone and combined use of vitamins $\mathrm{E}$ and $\mathrm{C}$ caused an inhibitory influence on the intensity of the processes of oxidative modification of proteins and stimulating - on the activity of enzymes of the antioxidant protection system. This influence is due to both direct and indirect action of the tested vitamins on the organism of chickens. It is necessary to consider different mechanisms of antioxidant action and place of action - vitamin $\mathrm{C}$ realizes its effect in the aqueous phase (cytoplasm), and vitamin $\mathrm{E}-$ in the lipid 
layer of membranes. It should be noted that such a wide range of vitamin $\mathrm{C}$ action under stress is probably not only related to its antioxidant activity. The regulatory influence of vitamin $\mathrm{C}$ may indicate the transcription processes of the corresponding enzymes, or the effect mediated by the influence of its derivatives. Vitamin $\mathrm{E}$ is known to exert its antioxidant action primarily in the cell membranes by breaking the chain of LO processes. A wide regulatory range of the influence of vitamin $\mathrm{E}$ on membrane processes has also been noted - regulation of membrane-bound enzymes (cyclooxygenase, protein kinase C, 5-lipoxygenase, and phospholipase $\mathrm{A}_{2}$ ), membrane stabilization processes, and the influence on the immune response (Zingg \& Azzi, 2004).

\section{Conclusions}

The inverse relationship between the content of ketone and aldehyde OMP products is ascertained in the blood of broiler chickens from the level of vitamins $\mathrm{E}$ and $\mathrm{C}$ in the ration. At the same time, these changes were more expressed in the blood of chickens, which were used vitamin $\mathrm{C}$, as well as vitamin $\mathrm{C}$ and $\mathrm{E}$ at 34 and 41 days of age.

Additional introduction to the ration of chickens vitamins $\mathrm{E}$ and $\mathrm{C}$ caused an increase of glutathioperoxidase and superoxide dismutase activity and increased levels of restored glutathione in the blood of chickens, especially at 34 and 41 days of age.

\section{References}

Armstrong, D. (2002). Oxidative Stress Biomarkers and Antioxidant Protocols. Totowa. New Jersey: Humana Press Inc.

Calderwood, S., Murshid, A., \& Prince, T. (2009). The shok of aging: molecular chaperones and the heat shok response in longevity and aging - a mini-rewiew. Gerontology, 55(5), 550558. doi: $10.1159 / 000225957$.

Flohe, L. (1989). Glutathione: chemical, biochemical and medical aspects. Pt. A.: Coenzymes and cofactors V.3. N.Y.: J. Wiley and sons.

Gutyj, B. V., Gufriy, D. F., Binkevych, V. Y., Vasiv, R. O., Demus, N. V., Leskiv, K. Y., Binkevych, O. M., \& Pavliv, O. V. (2018). Influence of cadmium loading on glutathione system of antioxidant protection of the bullocks'bodies. Scientific Messenger of Lviv National University of Veterinary Medicine and Biotechnologies, 20(92), 34-40. doi: 10.32718/nvlvet9207.

Harwell, B. (2007). Biochemistry of oxidative stress. Biochemical Society Transactions, 35(5), 1147-1150. doi: 10.1042/ BST0351147.

Hopps, E., Noto, D., Caimi, G., \& Averna, M. (2010). A novel component of the metabolic syndrome: the oxidative stress. Nutrition, Metabolism and Cardiovascular Diseases, 20(1), 72-77. doi: 10.1016/j.numecd.2009.06.002.

Iskra, R. Ja., \& Janovich, V. G. (2012). Vlijanie hlorida hroma na perekisnoe okislenie lipidov i aktivnost' antioksidantnoj zashhity v tkanjah krys. Biomedicinskaja himija, 58(4), 418-428 (in Russian).

Jeschke, M. G. Chinkes, D. L., \& Finnerty, C. C. (2008). Pathophysiologic response to severe burn injury. Ann Surg, 248(3), 387-399. doi: 10.1097/SLA.0b013e3181856241.
Karadas, F., Pappas, A. C., \& Surai, P. F. (2005). Embryonic development within carotenoid-enriched eggs influences the posthatch carotenoid status of the chicken. Comparative biochemistry and physiology. Part B, Biochemistry \& molecular biology, 141(2), 244-251. doi: 10.1016/j.cbpc.2005.04.001.

Kots, V. P. (2005). Vzaiemodiia vitaminiv A i E ta riadu mikroelementiv v orhanizmi kurei zalezhno vid rivnia v kormi: avtoref. dys. na zdobuttia nauk stupenia kand. biol. nauk: spets. 03.00.13 "Fiziolohiia liudyny i tvaryn". Kh., 21 (in Ukrainian).

Lavryshyn, Y. Y., \& Gutyj, B. V. (2019). Protein synthesize function of bulls liver at experimental chronic cadmium toxicity, Scientific Messenger of Lviv National University of Veterinary Medicine and Biotechnologies. Series: Veterinary sciences, 21(94), 92-96. doi: 10.32718/nvlvet9417.

Lavryshyn, Y. Y., Varkholyak, I. S., Martyschuk, T. V., Guta, Z. A., Ivankiv, L. B., Paladischuk, O. R., Murska, S. D., Gutyj, B. V., \& Gufriy, D. F. (2016). The biological significance of the antioxidant defense system of animals body. Scientific Messenger LNUVMBT named after S. Z. Gzhytskyj, 18, 2(66), 100111. doi: $10.15421 /$ nvlvet 6622

Lu, W. C., Chen, C. J., Hsu, H. C., Hsu, H. L., \& Chen, L. (2010). The adaptor protein $\mathrm{SH} 2 \mathrm{~B} 1 \beta$ reduces hydrogen peroxideinduced cell death in PC12 cells and hippocampal neurons. Journal of Molecular Signaling, 5(17), 5-17. doi: 10.1186/1750-2187-5-17.

Malakhov, V. O., \& Monastyrskyi, V. O. (2010). Suchasni uiavlennia pro imunoneiroendokrynnu systemu v normi ta pry patolohii. Novosti mediciny i farmacii, 316, 63-69 (in Ukrainian).

Martyshuk, T. V., Gutyj, B. V., \& Vishchur, O. I. (2016). Level of lipid peroxidation products in the blood of rats under the influence of oxidative stress and under the action of liposomal preparation of "Butaselmevit". Biological Bulletin of Bogdan Chmelnitskiy Melitopol State Pedagogical University, 6(2), 2227. doi: 10.15421/201631.

Mudrak, D. I., \& Ohorodnyk, N. Z. (2007). Biokhimichni pokaznyky krovi husei pry dii vitaminiv E i S ta selenu. Nauk.tekhn. biul. Instytutu biolohii tvaryn UAAN i DNDKI vetprep. ta korm. dobavok, 8(1-2), 49-52 (in Ukrainian).

Mudrak, D. I., \& Vishchur, O. I. (2011). Kilkist T- i V-limfotsytiv ta yikh funktsionalna aktyvnist u krovi husei za riznoho rivnia vitaminiv E i S u ratsioni. Biolohiia tvaryn, 13(1-2), 427-430 (in Ukrainian).

Park, I., \& Yun, Y. (2009). Transmembrane adaptor proteins positively regulating the activation of lymphocytes. Immune Network, 9(2), 53-57. doi: 10.4110/in.2009.9.2.53.

Pehrson, B., Knutsson, M., \& Gyllensnard, M. (1989). Glutathione peroxidase activity in heifers fed diets supplemented with organic and inorganic selenium compounds. Sweed. T. Agr. Res., 19(1), 53-56.

Vannuechi, H. (1991). Interaction of vitamins and minerals. Arch. Latinoamer. Nutr., 41(1), 9-18.

Ward, P. A. (2010). Oxidative stress: acute and progressive lung injury. Annals of the New York Academy of Sciences, 1203, 5359. doi: $10.1111 / \mathrm{j} .1749-6632.2010 .05552 . x$.

Ziech, D., Franco, R., Georgakilas, A. et al. (2010). The role of reactive oxygen species and oxidative stress in environmental carcinogenesis and biomarker development. ChemicoBiological Interactions, 188(2), 334-339. doi: 10.1016/j.cbi.2010.07.010

Zingg, J. M., \& Azzi, A. (2004). Non-Antioxidant Activities of Vitamin E. Current Medicinal Chemistry, 11(9), 1113-1133. doi: 10.2174/0929867043365332. 